\title{
БИНАРНАЯ ОППОЗИЦИЯ «ВЕРХ-НИЗ» В ЯЗЫКОВОЙ КАРТИНЕ МИРА (НА МАТЕРИАЛЕ РУССКОГО И КАБАРДИНО-ЧЕРКЕССКОГО ЯЗЫКОВ)
}

\section{BINARY OPPOSITION «TOP-BOTTOM» \\ IN THE LINGUISTIC PICTURE OF THE WORLD (MATERIAL OF RUSSIAN AND KABARDINO-CIRCASSIAN LANGUAGES) \\ Z. Bizheva \\ Z. Dzagova}

Summary: In this article the binary opposition in the Adyghe and Russian, ACM «top-bottom». It denotes a culturally significant metaphorical opposition, «penetrating» different languages and fixing similar ideas and directions in the estimated comprehension of reality by different peoples. And also language data of many cultural traditions allows to distinguish two types of spatial orientation:

1) real;

2) mental.

Keywords: binary opposition, linguocultural aspect, concept,» top bottom», culture, spatial orientation.

\author{
Бижева Зара Хаджимуратовна \\ д.филол.н., професссор, Кабардино-Балкарский \\ государственный университет \\ Дзагова Залина Владимировна \\ Соискатель, Кабардино-Балкарский \\ государственный университет \\ z.dzagova@yandex.ru
}

Аннотация: В данной статье рассматривается бинарная оппозиция «верхниз» в адыгской и русской ЯКМ. В ней обозначается культурно значимый метафорический код, «пронизывающий» разные языки и фиксирующий схожие представления и направления в оценочном постижении действительности разными народами. Выявлено, что языковые данные культурных традиций позволяют различать два типа пространственной ориентации:

1) реальную;

2) мысленную.

Ключевые слова: бинарная оппозиция, лингвокультурный аспект, концепт, «верх - низ», культура, пространственная ориентация.

Опираясь на данные толковых словарей и Национального корпуса русского языка, можно констатировать, что диада «верх - низ» лежит в основе интерпретации явлений, принадлежащих эмоциональной, этической, религиозной, социальной, гносеологической сферам жизни.

В этической сфере верх символизирует нравственность, благородство, духовность; низ - безнравственность, подлость, бездуховность: высокие - низкие помыслы, возвысить - унизить.

Оппозиция «верх - низ» вписывается в мировоззренческую сетку координат, состоящую из разных бинарных противоположностей: пространственных (верх - низ, право - лево, перед - зад, близкий - далекий), параметрических (большой - маленький, широкий - узкий), цветовых (белый - черный, яркий - тусклый), временных (весна - осень, день - ночь) и т. д., которая помогает человеку ориентироваться в многообразном окружающем мире. Каждая из оппозиций занимает в этой системе координат особое место, привнося свой штрих в общее оценочное «полотно» и отражая глубинные архетипические связи. Таким образом, наблюдение за явлениями действительности, выделение их важных параметров и свойств позволяет человеку наделять данные явле- 
ния аксиологическими признаками, формировать оценочную шкалу и, наращивая символические смыслы, интерпретировать феномены, принадлежащие умопостигаемым сферам - эмоциональной, этической, гносеологической и т. п.

Определение сфер, в которых проявляется оценочный характер метафорической диады «верх - низ», важно для понимания сложного механизма оценивания действительности - посредством последовательного освоения человеком (через свои переживания, через интуицию) бинарной оппозиции: от понимания значимости ее физических свойств для практической деятельности к освоению значимости ее физических свойств для оценочной и классифицирующей деятельности и в конечном счете для языкового моделирования мира, осознания его сложности и многоаспектности [5,с.187].

Концепты «верх» и «низ» издавна отражаются в сознании человека в их неразрывной связи и символизируют верх как нечто божественное, непостижимое, как начало чего-либо, как более недоступное, а низ как показатель более реального, доступного, возможного. В оценочном плане связь концептов отождествляется с коннотацией «низ как все, что притягивается к земле, а верх - выше земли» $[7$, с.158].

Оппозиция «верх - низ» является наиболее значимой для большинства культур, мифологические картины изображают мир преимущественно по вертикали. Зачастую данная оппозиция «трактуется как противопоставление неба и земли, вершины и корней мирового древа» $[7$, c.154].

Бинарная оппозиция «верх - низ», подобно другим пространственным оппозициям, способна выполнять функцию одного из «классификаторов, позволяющих выражать менее наглядные парные соотношения: «добро зло», «свое - чужое», «душа-тело» и т.д.» [3, с. 32].

Развитием дуалистического восприятия пространства, основанного на различии правой и левой руки, аргументируются и другие формы дуализма «природного» происхождения, к которым относится и противопоставление «верх-низ». Говоря о положении человека в пространственной ориентации в этом смысле, необходимо отметить прежде всего следующее.

Вертикальная поза человека - нормальное положение человека в пространстве - считается «началом координат, куда человек ставит себя, воспринимая и представляя пространство...» $[7, \mathrm{c.47}]$.

Как и во многих культурных традициях, в адыгской и русской языковых картинах мира представления о «верхе» и «низе» связаны с головой и ногами. В кабар- динском языке это находит свое отражение прежде всего в употреблении глаголов направления движения - «подняться» (дэк1уеин), «спуститься» (къехын, илъабжьэмк1э ехын), а также модификаторов «верх; наверху» (ищхьэмк1э) и «низ; внизу» (илъабжьэмк1э). Здесь речь идет, естественно, о пространственной ориентации относительно головы и ног человека.

Языковые данные многих культурных традиций позволяют различать два типа пространственной ориентации:

1. реальную;

2. мысленную.

Это можно продемонстрировать на примере адыгской и славянской языковых картин мира. Речь идет о глаголах направления движения, указанных ранее: дэк1уеин (подняться) и къехын (спуститься), и относительных пространственных концептах «низ; внизу» и «верх; наверху» [8,с.147].

Адыгский вариант данных высказываний предлагается для сравнения с русским: он поднялся на гору - Ар бгым дэк1 уеящ. Он ушел в «министерство - Ар министерствам дэк1уеящ.

В первом высказывании пространственная ориентация относительно чего? кого? находится выше от земли, чем местонахождение «субъекта и замещения», т.е. использование глагола «подняться» предопределено географическими факторами. Это характерно для сравниваемых языковых картин мира. И совсем иными факторами задана пространственная ориентация во втором примере относительно министерства в русской языковой картине мира. Второе высказывание здесь может быть сделано человеком, работающим в подчиненном министерству учреждении, употребление глагола «подняться» предопределяется социальным статусом «субъекта движения». Если же «субъект перемещения» работает в государственном учреждении (например, в министерстве) и едет в какое-либо ведомственное учреждение, нужно будет употребить глагол «спуститься» $[4, c .52]$.

Таким образом, можно говорить о существовании в естественном языке двух типов ориентации в пространстве. Первый тип можно условно назвать реальной (или природно-естественной) ориентацией, при которой действуют физические факторы. Второй тип можно было бы назвать мысленной (или социально-культурной) ориентацией, которая задается факторами социально-культурного порядка. Одна и та же ситуация в зависимости от данных типов пространственной ориентации может быть выражена двумя синонимичными высказываниями, содержащими в себе прямо противопоставленные по смыслу предикаты. Имеются в виду высказывания: «Я 
поехал в министерство» - в смысле «поднялся» и «Я поехал в министерство» - «спустился» [6, с.165].

В обоих предложениях «дэк1уеин» предполагает пространственную ориентацию и относительно горы, и относительно министерства выше от земли, чем местонахождение субъекта перемещения.

Пространственная ориентация в обеих ситуациях задана в адыгской языковой картине мира ишь топографическими факторами. Социально - культурной ориентации (вернее, иерархической) в данном случае нет. Однако это не позволяет утверждать, что в адыгской языковой картине мира отсутствует «мысленная» ориентация. Так, когда о ком-то говорят, что он «хорошо (высоко) поднялся» (ар ф1 ыуэ дэк1уеящ), такая оценка-ориентация задана, соответственно, не топографическими, а социально-культурными факторами.

«Мифологический» фактор заданности противопоставления «верх-низ», соотнесенный с другой оппозицией - «плохой - хороший», находит отражение во многих адыгских приметах. Например: Сабийм и дзэ ш1ы1ур япэ кьэк1мэ, куэдрэ мыпсэууэ мал1э, и ищ1агъыдзэр япэ къэк1мэ, куэдрэ мэпсэу, жа1эрт. - Если у ребенка вначале вырастают верхние зубы, долго не живя, умирает (он); нижние если вначале вырастут, долго живет, говорили.

Голова, символизирующая в средневековом менталитете разум и духовную жизнь, в адыгской и русской языковых картинах мира также отождествляется со всем разумным, благочестивым, важным, основным. Голова символизирует активное интеллектуальное гармоничное начало. С головой соотносятся добрые намерения человека. Она олицетворяет ум. Такое олицетворение всего «высокого», духовного (в отличие от «земного», «нижнего | низменного)» мира - по антропологической модели Космоса) вписывается в контекст мифа о так называемом «мировом дереве», согласно которому голове человека соответствует крона «мирового дерева», а ногам - корни. В адыгской лингвокультуре - «корень» лъабжьэ (от «нога»: лъакъуэ).

Помимо оппозиции «верх (голова) - низ (ноги)», концепт «щхьэ» (голова) образует в рассматриваемых картинах мира и другие оппозиции, многие из которых представляются этноспецифичными. Они приобретают вторичные значения в контексте «верх - низ»: «возвышенное низменное» [5,c.54].

Сравним адыгские и русские идиомы в данном контексте каб.-русс.:

1. «Младший-старший»: «Почетный-непочетный»: например: Зи нэхъыжъ зымылъытэм и ищхъэ ылъытэжыркъым - Своего старшего кто не почитает, свою голову не почитает. Зи щхьэ пщ1э хуэзмы- щ1ыжым пщ1э и1экъым - Свою голову кто не почитает, почета не имеет. Уи адэ - анэм и напэр тумых -Не позорь честь отца и матери; русс: Высоко поднял (умом), да низко опустил; Чин чина почитай, а меньшой садись на край; Не хвались отцом, а хвались молодцом (сыном - молодцом); Не хвались родителями, а хвались добродетелями; Молодой журавль высоко взлетел, да низко сел.

Главное требование к подрастающему поколению у адыгов и славян - уважение к старшим, требование не посрамить их чести.

2. «Плохой - хороший»: каб. Зи мы1уэху зезыхуэм и щхьэм баш тохуэ - Не своим делом кто занимается (не в свое дело вмешивается), на его голову палка попадает; русс: У него голова трухой забита: В добрую голову сто рук; Плохой мастер, плоха и работа.

3. Умный - неумный»: каб.: Зи щхъэ илъым и шхьэ ирилътынщ - У кого в голове есть (лежит), тот со своей головой тебя сравнит (своей голове себя уподобит). Дэтхэнэ зы унафэми гупсысэ хуейщ Всякое решение любит рассуждение; - русс: Умная голова сто голов кормит, а пустая и себя не прокормит; Легко ранили, а головы не нашли; Голова на плечах (кто-либо достаточно умён и сообразителен).

4. «Голова-ноги (хвост)»: каб: Уи щхьэ зыф1эмы1ейм уи лъакъуи и ф1э1ейкъым - Твоя голова кому неплохой кажется, твои ноги тоже кажутся неплохими. Уи к1э здимык1ынум уи щхъэ иумъй1у - Твой хвост куда не пройдет, свою голову не просовывай; - русс: Дурная голова ногам покою не даст; Голова у ног ума не просит; Не удержался за гриву, и за хвост не удержишься.

5. «Голова-имя (суть)»: Уи щхъэ зи жагъуэм уи ц1э ф1э1ейщ - Твоя голова кому неприятна, твое имя плохим кажется.

6. «Голова-сердце»: позитивное-негативное»: Уигу ф1ы имылъым и щхьэ ф1ы къехъулъэркъым - В чьем сердце хорошее не лежит, его голове хорошее не случается. Зи щхьэр къабзэ, зи гур бзаджэ - Чья голова чистая, а сердце злое. Щхьэ къабзэ гу бзаджэ - Голова чистая - сердце злое.

«Свое-чужое»: каб: Зи щхьэ 1уэху зыхуэмыщ1эжыр хамэ 1уэхук1э ф1ыщ - Своей головы дело кто не умеет делать, (тот) чужим делом упорно занимается. Зи щхьэ мыузым уи щхьэ уз хуумы1уатэ - (Тому) чья голова не болит, твоей головы боль не рассказывай. Уи щхъэ иумыпэсымк1э нэгъуэщ1ым хуэмыупсэ - Своей головы что не считаешь достойным, другому не предлагай. 3и щхъэ зыхуэмы1ыгъыжым щхъэ 1ыгъын къещтэ - Свою голову кто не может (со)держать, за держание (другой) головы берется, которую надо содержать, берет); - русс: Свою голову положу, да хвою с плеч снесу; Сваливать с 
больной головы на здоровую (слагать свою зину на других); Своя рубашка ближе к телу; Чужие руки легки, да не к сердцу; У кого не болит, у того не свербит; Кому от чужих, а нам от моих; Чужим здоровьем болен (о завистливых), Свою болячку не своим здоровьем лечить; Что русскому здорово, то немцу смерть.

7. «Голова (суть)- язык (рот, голос)» каб: -Жъэл1ык1уэ нэхърэ щхьэ сык1уэ -Чем рта (языка) представитель, лучше головы представитель посредник). И щхьэ мыжьрэ и жьэр бзаджэу - Его (ее) голова не расчёсанная, (а) его (ее) рот (язык) злой (желчный). И щхъэр матэщ, и жьэр джатэщ - Его (ее) голова - корзина, его (ее) рот - меч. Щхъэ ц1ык1у макъышхуэ - Голова маленькая - голос громкий.

Таким образом, метафорическая номинация понятий верха (головы) и низа (ног) сходна в адыгской и русской лингвокультурах: голова олицетворяет «высокое», духовное, положительное, а ноги - «низменное», отрицательное в обеих этнических оппозициях.

В контексте бинарной оппозиции «верх - низ» возникают и вторичные прочтения с этноспецифичными конфигурациями, что является предметом описания в нашей специальной работе.

\section{ЛИТЕРАТУРА}

1. Бижева 3.Х. Адыгская языковая картина мира. Нальчик: Эльбрус, 2000. 128 с.

2. Бижоев Б.Ч. Грамматические и лексико-фразеологические проблемы кабардино-черкесского языка. - Нальчик: «Эльфа», 2005. - 350с.

3. Битокова С.Х. Образная концептуализация ума в кабардино-черкесском языке // Вестник Адыгейского государственного университета, 2008. - Выпуск 6. - C.20-26.

4. Гак В.Г. Языковые преобразования. - М., 1998.

5. Колесов В.В. Концепты культуры // Вестник Петербургского ун-та, Сер.2. -1992. -Вып.4. -С.30-39.

6. Кумахова 3.Ю. Развитие адыгских литературных языков. - М.: Наука, 1978. -280 с.

7. Маслова В.А. Лингвокультурология. - М.: Издательский центр «Академия», 2001. - 208 с.

8. Толстой Н.И. Язык и народная культура. - М., 1996.

9. Трубецкой Н.С. Т. 77. Избранные труды по филологии: Переводы/ Сост. В.А. Виноградова и В.П. Нерознака; Под общ. ред. Т.В. Гамкрелидзе и др.; Послесл. Т.В. Гамкрелидзе и д р.- М.: Прогресс, 1987. - 560 с.

( ) Бижева Зара Хаджимуратовна , Дзагова Залина Владимировна (z.dzagova@yandex.ru).

Журнал «Современная наука: актуальные проблемы теории и практики» 